\title{
GLOBALISATION: IMPLICATIONS FOR HEALTH CARE DELIVERY IN DEVELOPING COUNTRIES
}

\author{
Prof Louise de Villiers \\ D Litt et Phil \\ Associate Professor, Department of Health Studies, University of South Africa \\ Corresponding author: dvilll@unisa.ac.za
}

Keywords: globalisation; health care; ubuntu; health sciences education

\section{SUMMARY}

Globalisation entails a rapid increase in economic, technological and cultural exchange, which flows from economically and technologically dominant nations to less dominant nations. Many of the underlying principles of globalisation are contradictory to traditional values. Globalisation could aggravate marginalisation of vulnerable communities in Africa. On the other hand globalisation is regarded to provide developing and under-developed nations an opportunity to escape from a cycle of under-development, poverty, inadequate access to health care, and ill health. Health care professionals could contribute towards optimising the benefits of globalisation towards enhancing health and development in their communities. This requires that they reconceptualise their roles and the nature of health sciences education programmes. The author discusses the main characteristics of globalisation, and its implications for developing countries and traditional lifestyles.

\section{OPSOMMING}

Globalisering behels ' $n$ toename in ekonomiese, tegnologiese en kulturele uitruiling vanaf ekonomies-dominante na ekonomies minder-dominante samelewings. Talle beginsels onderliggend tot globalisering is in teenstelling met tradisionele waardes. Globalisering kan ook die marginalisering van kwesbare gemeenskappe vererger. In teenstelling hiermee, kan globalisering ontwikkelende en onderontwikkelde gemeenskappe help om te ontsnap uit ' $n$ siklus van onderontwikkeling, armoede, onvoldoende toegang tot gesondheidsorg en swak gesondheid. Gesondheidsorgdeskundiges kan meewerk om die voordele van globalisering te optimaliseer ter bevordering van gesondheid en die ontwikkeling van gemeenskappe. Dit vereis ' $n$ herkonseptualisering van hulle rolle en die aard van opvoedkundige programme vir gesondheidsorg. Die outeur bespreek die hoofkenmerke van globalisering, en die implikasies daarvan vir ontwikkelende lande en tradisionele lewenswyses. Die rol en verantwoordlikhede van gesondheidsdeskundiges word uitgespel. 


\section{INTRODUCTION}

Globalisation entails a rapid increase in economic, technological, and cultural exchange, flowing from economically and technologically dominant nations to less dominant ones. Globalisation is perceived to have both positive and negative consequences. While globalisation can contribute towards helping African nations towards improved economic and social development, ill-conceived initiatives are sure to fail or may lead to the exploitation of ordinary people. Health care professionals could contribute to optimise the benefits of globalisation by serving as client-advocates, communicating specific needs and culture-congruent solutions to stakeholders. This requires that they reconceptualise their roles and their educational programmes accordingly. The purpose of this article is to reflect on how globalisation impacts on developing countries and traditional life of people living in developing countries, particularly Africa. Health care professionals could assist their clients in becoming active role players in a globalised world to secure their own health and development. The author therefore also outlines the implications of globalisation for the role of health care professionals and health sciences education.

\section{MAIN CHARACTERISTICS OF GLOBALI- SATION}

Globalisation is a new international system, which has replaced the cold war system. It involves processes of interconnecting the world's inhabitants with respect to the economic, political, technological, environmental and cultural aspects of their lives (Greenberg \& Baron, 2003:14). It is a set of ongoing processes of inevitable integration of markets, nation-states and technologies, enabling individuals and corporations to reach around the world more quickly, more comprehensively and more cheaply than ever before (Friedman, 2000:8-9; Giddens, 1999a:2).

Globalisation is characterised by one word, namely the "web", and its overarching feature is integration or connectedness. The main means of being interconnected is the internet, where no one is entirely in charge (Friedman, 2000:7, 8, 10). In this trans-national world geographic and human borders have been erased, thus weaving the world together into what is rapidly becoming a global village. Geographic distance becomes a factor of diminishing importance in the establishment and maintenance of cross border economic, political, and socio-cultural relations, which have become unhindered by time and space. The world is seen as a global marketplace, as there is a flow of trade, capital and labour across borders (Friedman, 2000:xvi).

Technological advances facilitate globalisation. Affordable, integrated information-communication technologies are readily available to institutions, organisations, and individuals. Communication is faster and cheaper than ever before (Friedman, 2000:47, 48). The internet is increasingly becoming the tool of trans-national corporations to market their services and products around the world. Individuals are empowered to exchange knowledge and information, and to render or utilise services on the internet. Consumers have limited, or no social relations, with the people who produce the goods and services that they consume. An example is company telephone answering systems informing one to press a specific button for a specific service; information can be obtained without any human interaction whatsoever (Friedman, 2000:51).

Globalisation entails increasing interaction or integration of national economic systems through the growth in international trade, investment and capital flows. Company operations, trade and services are offered globally. The driving idea is free market capitalism. This entails opening, deregulating, and privatising economies to enhance competitiveness and attract the foreign investment needed for economic growth and wealth creation (Friedman, 2000:xviii, 9). Wealth is created by the development of information, goods, and services ranging from media, to education and software. Ideally, the potential for wealth creation becomes geographically dispersed, as the world becomes rich in opportunity and benefits for all (Friedman, 2000:51; Evans, 1992:1).

The defining measurement is speed. Globalisation came about at a very fast pace and continues to unfold at great speed. Innovation replaces tradition. Innovations are made obsolete or turned into a commodity at the speed of light. The global economic system is driven by creative destruction. Old and deficient services, products, or companies are destroyed and replaced with new, more efficient ones. People need to constantly adapt to changed situations and ways of doing things 
(Friedman, 2000:10-11). It is a future-directed economic system which is continually breaking away from the past in quest of the future. The notion of risk replaces the traditional stance of seeing man's destiny as being determined by fate, luck, the will of God, or sorcery. This new view threatens traditional points of view, where the past is perceived to structure the future (Giddens, 1999a:5; Giddens, 1999b:2).

It is difficult to live in a globalised world, as people are faced with competitiveness, uncertainty and insecurity (Friedman, 2000:11-12). The defining anxiety is fear of rapid change brought about by unseen forces, such as trans-national corporations and the global media, which have the potential to change one's job, workplace, or community. Friends and enemies have now become competitors and it is necessary to function in the face of fierce competition (Friedman, 2000:7-12; Louw, 2001:51). Interconnectedness and speed result in trends and problems spreading like a virus. Examples of socioeconomic problems and their global consequences include the emerging markets and the dot-com crises (Friedman, 2000:xvi; Greenberg \& Baron, 2003:14). Health problems such as human immunodeficiency virus (HIV/AIDS) and severe acute respiratory syndrome (SARS) have global implications and require a united problem-solving approach.

The major role players are: the superpower United States of America (USA), the super-markets (investors and financial centres), and the super-empowered individual. Although the USA is the only superpower, it does not influence the world on its own. The attitudes of millions of investors, who rapidly move their money around the world, or speculate against a currency, have the power to trigger the downfall of governments. Individual countries shift power from the state and its bureaucrats to the private sector, entrepreneurs, and individuals. Bureaucrats, industrialists, and business people, who previously enjoyed the fruits of government protection and monopolies, experience a loss of power. The same applies to labour unions and workers who previously received comfortable benefits regardless of the achievements of their companies (Friedman, 2000:336337). Individuals have more power than ever before to influence markets and nation-states by putting their energy into interest groups beyond the level of nationstates (Friedman, 2000:14). The ability of governments to apply censorship, or to exercise economic, ideo- logical, and cultural control is inhibited. Armed with an unprecedented access to knowledge and information about world-events, individuals can revolt against governments, demand participation in decision-making, and demand that their needs and expectations be met. They expect a good life and access to the best and cheapest goods and services from anywhere in the world (Evans, 1992:5; Giddens, 1999e:3-4).

Individualism is prevalent and ideally individuals are respected according to their merit, ambition, and ability. Individuals are considered to be unique and are free to pursue their own interests. In a democratic sense, in an ideal world, individuals pursuing their own interests will collectively and ultimately serve the interests of society (Evans, 1992:1). The family as an economic unit has been replaced by family that is based on the principle of emotional democracy. A marriage relationship, which is based on the principle of emotional democracy, is characterised by intimacy, equality, trust and openness. Alternative family forms such as co-habitation and single parent units have become evident (Evans, 1992:2; Giddens, 1999d:1-6).

The production and distribution of goods are divorced from other concerns, such as politics, religion, and ethics. Political and religious belief-systems are being subsumed under the power and technology of the international free-market system (Evans, 1992:4). There is a rapid social and cultural exchange between nations and the world tends to become culturally homogeneous. There is increased evidence of Americanisation and the spread of a western consumer culture (Friedman, 2000:9; Evans, 1992:1). On the other hand, the emergence of an increasingly cosmopolitan global culture, in which various cultures and cultural trends coexist, is also evident.

Globalisation results in accelerated trans-border mobility and urbanisation. Urbanised peoples' lifestyles are intimately linked with global fashion, food, markets, and entertainment trends (Friedman, 2000:13). People leave behind the culture of the nation-state as their consciousness globalises. It does not matter in which country a product was made. What is important is branding and quality, considering its intended purposes (Evans, 1992:2).

GLOBALISATION AND DEVELOPING 


\section{SOCIETIES}

Everyone is affected by globalisation, either positively or negatively. Global markets generate both capital and chaos or disruption that impact upon traditional business-practices, social structures, cultural mores, and environments (Friedman, 2000:329). Especially in developed countries, globalisation represents the drive for improvement, prosperity and modernisation. The benefits may be defined in terms of shopping in integrated markets and having access to sophisticated technology. In theory, people in developing countries can also enjoy these "benefits". However, in practice people have unequal access to the new markets, technologies, and opportunities and derive unequal benefits from them (Friedman, 2000:33). In some instances developing countries have become the dumping ground of unwanted equipment, pesticides and medicines (Giddens, 1999a:4).

While free-market capitalism operates across national borders, there is ample evidence of the existence of subsistence economic systems in developing countries. In many areas people still draw water from wells, gather firewood, engage in traditional agricultural practices, and struggle to survive (Friedman, 2000:33). For these people globalisation and its perceived benefits do not make much sense. It is difficult to visualise how illiterate people who make a living out of logging or fishing, who have never encountered a computer, will be able to survive in a globalised economy (Friedman, 2000:330). Poverty-stricken African countries are falling further behind and it will continue to be very difficult to escape from the spiral of low educational levels, unemployment, poverty, crime, violence and disease (Friedman, 2000:341). While modern life is characterised by speed and rapid change, life in a rural village moves slowly, and time is conceptualised to be following a cyclic pattern of social activities or natural cycles (Giger \& Davidhizar, 1999:93-100, 105-108, 109-111; Malan, 1989:43). Rural communities may resist demands that they adhere to time-structured schedules and do future planning or projections.

Those who live in developed countries experience many benefits due to increased mobility and urbanisation. However, urbanisation in developing countries is also accompanied by living in overcrowded shantytowns, with inadequate infrastructure and services. In this world of global travel, the lives of villagers or shantytown dwellers are confined to a radius of a few miles from home. This is a far cry from being a global citizen.

Economic reform is necessary to attract foreign investment, and enhance economic growth and wealth creation. However, it would be difficult to transform agrobased economies into knowledge-based economies. Furthermore, many African countries still struggle to replace their existing economic policies, overcome the existence of inadequate infrastructure, and reduce telecommunication costs. Those governments who derived their inspiration from ideologies such as socialism and nationalisation tend to oppose the idea of creating a leaner state and allowing market forces to regulate the economy. Opponents of globalisation criticise it for being a worldwide drive toward a globalised economic system, dominated by supranational corporate trade and banking institutions that are not accountable to democratic processes or national governments. Measures to ensure responsible management of the economy and donor funds, and to prevent speculative attacks on local currencies may prove to be unpopular. Moreover, in some instances where privatisation has occurred, it led to empowering a small elite group to the exclusion of the poor majority (Friedman, 2000:330, 341-342). This serves to worsen the plight of the poor and hamper efforts to portray the theoretical benefits of reform in a positive light.

Supporters of globalisation believe that it has the potential to enhance wealth creation based on international economic trade. This will result in increased employment opportunities for highly skilled and multiskilled persons. For example, the establishment of call centres in India and South Africa, and the relocation of the activities of sections of large corporations to lowwage countries, create new employment opportunities in those countries (Friedman, 2000:52). On the other hand, subsistence farming and the informal business sector are being undermined, and many people lose their jobs or do not witness any improvement in employment opportunities. Machines are now performing many manual, repetitive tasks. Those who search for jobs, housing, and food daily, find that their governments are downsizing, and streamlining without providing a safety net for those who fall by the way side (Friedman, 2000:331, 333; Giddens, 1999a:5). Furthermore, many people experience unease about a lack in com- 
petencies necessary to compete in a globalised world, and are afraid of being left behind (Friedman, 2000:340). Health care professionals and community members alike are unlikely to have specific technological and cognitive skills to effectively and appropriately utilise information-communication technologies or participate on the global economic stage.

The internet provides an opportunity to gain access to knowledge, services, and development aid from around the world. Poor countries can now become major roleplayers by utilising available technologies and job creation opportunities optimally to further their developmental needs (Friedman, 2000:51). However, while globalisation is characterised by technological advances and connectedness, there is evidence of a digital divide between developed and developing countries, as well as between communities within a single country. This is due to educational and economic constraints, and a lack of the relevant infrastructure. Fixed mindsets complicate matters even further. People often argue that computers and communication systems are inappropriate given the levels of poverty and limited infrastructure in many developing countries, especially on the African continent. They often fail to consider obvious solutions such as using solar or battery energy sources, and wireless and satellite technologies. The digital divide could provide an opportunity for developing countries to leapfrog steps in the development of their infrastructure by investing in the internet, satellite technology and mobile telephones.

Many international initiatives are aimed at assisting developing countries to overcome the problems of limited availability of, and access to, information-communication technologies. However, access to technology alone would not necessarily make much difference in any given society. A holistic approach is required. In rural Ghana, sponsored learning centres provide, amongst others, basic training such as literacy training for adults. Internet access is also provided to local communities though business kiosks. However, resistance towards technology, language barriers, and illiteracy hamper utilisation of these services. Furthermore, the long-term viability of such initiatives is being restricted by the inadequate establishment, maintenance and expansion of the necessary infrastructure.

In some instances the global community attempts to bring the benefits of globalisation to remote villages. Electronic community centres have been established in steel shipping containers, for example. The Greenstar Foundation builds solar-powered community centres that deliver electricity, pure water, health and education information and wireless internet connection to villages in the developing world. Greenstar follows an ecommerce business model by recording and bringing local art, music, photo's, legends and stories to world markets through the internet. A percentage of the revenues from this "digital culture" is returned to the villages to support their ongoing, independent development. This is an indication that even the smallest and weakest political community can use the new markets and technologies to preserve their culture and identity, while also benefiting from employment opportunities, skills development and access to services (Friedman, $2000: 35)$. Netaid is a growing and international network of people and organisations committed to ending extreme poverty through education. This initiative is aimed at giving children access to schooling, food, shelter and counselling (Netaid, 2005). However, many developmental projects are implemented in an uncoordinated fashion. This results in fragmentation, duplication and the ineffective use of human resources. Local realities and constraints are often inadequately considered. Projects and programmes that were successful elsewhere are not necessarily relevant and viable considering the unique circumstances, problems and needs of specific communities. Furthermore, many programs offered by the international community are unaffordable because of the weakness of local currencies.

The problems that accompany globalisation could potentially lead to a backlash from, not only the poor and downtrodden, but also from the downwardly mobile middle classes who previously enjoyed protection in business or in the workplace. Such a backlash may come in the form of destroying the natural environment, as people might very nearly decimate what is left of the natural habitat in an effort to survive. In many countries the backlash came in the form of wave after wave of crime, instead of an organised opposition to globalisation (Friedman, 2000:335).

\section{GLOBALISATION VERSUS TRADITION}

As previously explained, globalisation is associated with cultural diffusion and multiculturalism. Tradition gives 
continuity, direction and form to life. As societies become de-traditionalised, people are forced to redefine their identity and sense of belonging (Giddens, 1999a:34). Without a sense of home and identity, life becomes meaningless. While adaptation to new cultural realities may be easy for some, it can also become so overwhelming that it threatens communities and their traditions (Friedman, 2000:31-32, 42). The impact of globalisation on traditional life will be discussed with specific reference to African tradition.

In a globalised world, the individual enjoys increased autonomy. Autonomy entails an increased responsibility to independently make choices and decisions. Selfidentity has to be constantly created and recreated in a continuously changing, competitive environment (Friedman, 2000:340-341; Giddens, 1999a:5). The African world-view (Ubuntu) acknowledges the significance of collective unity and group solidarity. These values are prevalent amongst groups who experience or have experienced poverty and deprivation and who cannot survive on individual initiative alone (Kotze, 1993:3; Mbigi \& Maree, 1995:8, 58). Traditional African life is communal and the individual becomes integrated into a network of mutual relations. The individual is not perceived to be independent from the group (Lubbe, 2004:81). Conformity, solidarity, and loyalty to the group are highly regarded. Empowering the individual is equated with dividing society (Mbigi \& Maree, 1995:58). Individualism is perceived to change the relationship of the individual to the state and community in a disintegrating fashion. On the other hand, criticisms have been voiced against African governments for establishing a system of oppressive communalism (Khoza, 1994:9). The question that arises is whether individualism destroys tradition, or whether it is a liberating force against oppression by those who abuse tradition to legitimise their power.

The traditional family is an economic unit, and family ties extend to include a broad kinship structure. Power relations and the authority of the dominant family member are clearly defined. In the modern world, the traditional family is seen to be a limiting factor for democracy and economic development, because what is needed are changed power relations between males and females, and parents and children (De Villiers \& Tjale, 2004:166-167; Giddens, 1999d:6). Globalisation may therefore threaten the traditional family structure and power relations, which may result in a sense of disintegration and insecurity among the members of such families.

Africans hold a deep respect for religious beliefs and practices, which are characterised by cross-fertilisation between the African ethos and Christianity (Teffo, 1994:9). There is an inextricable bond between man, the ancestors and God. Ancestral spirits act as intermediaries between man and God. The ancestral spirits enjoy the respect and honour of the living because the living relies on the ancestors for protection and prosperity. In addition to the belief in ancestral spirits, Africa knows a relatively widespread belief in nature spirits, manifestations of which are to be found in mountains, rivers, or in special stones (Lubbe, 2004:7981). Cultural diffusion and secularisation, which accompany globalisation, may shatter the religious beliefs, practices and experiences of those who still maintain traditional lifestyles.

Traditional societies are organised in terms of age and gender classes that provide a framework for orderly status distribution and social interaction. The distribution of wealth is made according to the prescriptions of status classification. Much status and respect are awarded to older persons. An older person is regarded to be more of a person than a younger one, because he/she has more to offer in the way of knowledge and experience, personal influence and power (Prinsloo, 1998:43). Globalisation exposes the youth to global trends and cultural forces that alienate them from their culture and traditions. Furthermore, the super-empowered individual enjoys much autonomy and influencing power. This has the potential to disrupt the traditional power relations between young and old, and male and female (Friedman, 2000:329).

In traditional societies, democracy is based on consensus and reconciliation, which are sought through lengthy discussions and shared decision-making. Conformity is cherished more than innovation. Tradition and continuity are valued, while difference is shunned. Cooperation is highly regarded while competition and exploitation of people are frowned upon. Profits, or capital accumulated, are shared with others (Prinsloo, 2001:60; Teffo, 1994:4). In contrast, in a capitalist society, it is standard practice to consult with clients on an individual basis. Swift decision-making and actions are 
required to beat or outperform the competition. Where capitalism meets tradition, it is necessary to utilise local decision-making structures and consultation processes to prevent resistance against, and the failure of, projects and programmes. However, this may decrease local communities' adaptability and competitiveness.

While the production and distribution of goods are divorced from other concerns such as politics, religion and ethics, Ubuntu dictates that social morality should be maintained. It ought to be manifested by accepting obligations towards others and by participating in social upliftment through reconstruction and development programmes. In the same vein, social and economic reconstruction and development should include moral development, because without such development massive amounts of money cannot guarantee real economic and social development (Teffo in Prinsloo, 1998:42). Some question whether Ubuntu could succeed in contributing towards development in Africa. According to Mbigi and Maree (1995:8), the spirit of Ubuntu has resulted in political liberation in South Africa, but not in meeting the challenges of reconstruction and development, because of a lack of personal accountability and commitment to live for one's country. This criticism gives impetus to those who argue that globalisation is the answer to eliminating underdevelopment and poverty. It is, however, debatable whether globalisation would contribute towards reconstruction and development through accountability and commitment towards a particular country, considering the demise of the autonomy of nation-states.

Ubuntu is deeply rooted in humanity and empathy in interpersonal relationships. Village life centres on a small group of people whose lives are intertwined. Human interaction is characterised by heartiness, harmonious participation and cooperation, and reciprocation, which flow from a shared world-view. Direct, open and honest lines of communication are maintained. Social relations are internalised in the extended family, and family life is emphasised, as is contact with distant relatives and friends. Such relations form a closelyknit social network, which promotes solidarity (Khoza, 1994:1; Makhudu, 1993:40-4; Prinsloo, 2001:58-59). In tribal societies, people have real social relations with the producers of the goods they consume (Evans, 1992:2). In a globalised world, many transactions and communication occur electronically. The relationship between service providers (or care-givers) and clients are viewed as a contractual relationship, which does not necessarily entail interpersonal contact. As a result, people may experience a sense of dehumanisation and marginalisation.

Ubuntu requires social responsibility, which is expressed in compassion and caring for the less privileged, the poor and orphans. Each person is viewed holistically by focussing on his/her physical, emotional, social and spiritual needs. The ultimate expression of regard for another is by showing concern spontaneously, and voluntarily assuming a self-imposed sense of duty towards those in need of care (Prinsloo, 1998:42). Community-based development programmes aimed at community empowerment, are more likely to lead to reconstruction and development than a capitalist approach towards economic reform and wealth creation.

\section{IMPLICATIONS OF GLOBALISATION FOR HEALTH CARE PROFESSIONALS}

\section{Role of health care professionals}

In the previous sections, globalisation, and its possible consequences for developing countries and traditional lifestyles, was debated with specific reference to Africa. Globalisation seems to be inevitable and its influence will continue to be felt throughout the world. Health care professionals are well positioned to assist local communities in coming to grips with globalisation, overcoming resultant problems, and ensuring that the benefits of globalisation filters down to grassroots level. It is necessary to assist communities to become independent and responsible global citizens, by fostering community empowerment through community development. What is needed is a reconceptualisation of the role of health care professionals and a renewed commitment towards maintaining an approach of interdisciplinary intervention to care.

Health care professionals act as client advocates by identifying the needs and concerns of local communities. They could then canvass politicians, donors, large corporations and community leaders to address those needs and concerns. They can positively contribute towards the prosperity and well-being of local commu- 
nities by mobilising stakeholders and influencing governments to adopt policies that would support foreign investment, economic growth, social stability and improved health.

As globalisation does not automatically ensure employment opportunities and wealth creation, renewed efforts are necessary to establish services supporting those who live with the consequences of unemployment, poverty, crime, violence and disease. Health care professionals, as caregivers, could establish poverty relief programmes and trauma counselling services. They can contribute towards strengthening health education and primary health care programmes in collaboration with other caregivers, such as pastoral counsellors. It is necessary to develop culture-congruent counselling programmes, aimed at helping people to adapt to the changing world order and to cope with the psychological and social problems that result from traditions being shattered. People need to be assisted in redefining their identities and in strengthening their sense of dignity, while living in a world that negates tradition and custom. In particular, marriage guidance and counselling could limit the effects of changing family structures and relations. Preventative interventions are implemented to avoid the emergence of addictions, which are largely absent where traditions are intact, but which increase with the advent of increased personal autonomy in a de-traditionalised environment (Giddens, 1999a:5). The establishment of cultural awareness workshops could assist communities in making sense of the cultural changes that accompany globalisation, and to cope with the consequences of change. Examples of such workshops include workshops aimed at helping communities to cope with the influences of an expanding consumerist culture, and workshops on how to interact with people from different cultural and religious backgrounds.

In traditional societies, people utilise the traditional health care system. Research in Botswana revealed that people also seek health care from the church to which they belong, and that various religious prescriptions and practices are followed to enhance health and well-being (Kgwatalala, 2003:92). Collaboration between health care professionals, traditional healers and religious leaders could contribute towards ensuring that the health-related benefits of globalisation filter through to communities at grassroots level. Health care profes- sionals could achieve this by campaigning for the establishment of the technologies and facilities required to secure access to telemedicine and personal health information systems, for instance. Access to such services can be secured through religious facilities, for example.

Health care professionals as agents of change could serve to recognise opportunities that would enable local communities to share in the benefits of globalisation. This could be achieved by promoting, in collaboration with local entrepreneurs, the utilisation of the internet to enhance access to global markets. Local art, folklore, produce and ecotourism, for instance, can be marketed and sold on a global scale. This represents a step towards supplementing a subsistence economy with a more modern economic approach. Care must, however, be taken to protect the cultural heritage of communities. Cultural revival initiatives should contribute towards fostering a sense of inclusiveness, against the global trend of individualism and fragmentation (Louw, 2001:46). Health care professionals could protect local communities by ensuring that the cultural products on offer in the global market place are authentic. It is necessary to resist any trend to turn cultural products into kitsch tourist goods that earn profits for entrepreneurs, while portraying a distorted view of local values. In addition, health care professionals could view the internet as a medium that gives marginalised people a voice. This could be achieved by documenting the personal narratives of peoples' lives and struggles and publishing it on an appropriate web site.

Health care professionals as protectors could intervene to prevent the exploitation and deprivation of vulnerable communities (Louw, 2001:53). For example, medications that have been discredited elsewhere are sometimes donated or sold at a greatly reduced price to marginalised communities. Health care professionals ought to protect the community against the establishment of inferior or inappropriate programmes, facilities or equipment.

In a context where high levels of illiteracy prevail, the role of the health care professional also entails being a mediator between the available information and people who need access to that information. Information that empowers communities to make informed decisions 
about health and development is readily available on the internet. However, this does not constitute increased access for those who are illiterate or poorly educated. Where necessary, access has to be negotiated though health care professionals and other caregivers. Health care professionals come into daily contact with the local community that they serve and understand their needs and abilities. This mediation role entails identifying appropriate information sources (such as web sites) and critically evaluating the information obtained from identified sources. Information sources that disseminate untested data and information, or those who market a specific brand or service to the detriment of ordinary people, are to be avoided. Health care professionals could ensure that the information obtained is filtered through to the community whether orally, in writing, or though local web sites that comprise hyperlinks to appropriate web sites. People generally seek access to information to support informed decision-making. Health care professionals could assist decisionmakers in making sound decisions based on appropriate information. Decision-makers can be assisted in understanding the decision-making process, as well as the local realities and constraints that influence their decisions. Health care professionals could give decision-makers guidance on how to consider potential consequences of various decision-options. They should consider the fact that a sound decision in the developed world may be inappropriate in a developing country.

As educators, health care professionals are well positioned to facilitate the establishment of basic technological literacy courses and training, aimed at educating communities about the importance of information and sources of information, especially the internet. Community members who are literate are taught how to search for information on the internet and how to evaluate web sites and their contents in terms of the purposes for which the information is sought. Alternatively, educated community leaders could be empowered to take responsibility for obtaining relevant information and disseminating it to the community.

\section{Education and training of health care pro- fessionals}

In a globalised world, people are being bombarded with information, which is often presented in a deconstructed format. To equip health care professionals with the ability to make sense of this, it is necessary to develop their information management and higher-order intellectual skills. Information management skills would enable them to seek, access, retrieve, interpret and appropriately utilise information. Persons who exercise higherorder intellectual skills tend to think at a conceptual level rather than at a level of rote-memorisation, and are able to go beyond the given information and to probe for and make connections (De Villiers, 1998:205; Fry, 1992:IX). This forms the basis for critical reflection and knowledge construction. Health sciences education should therefore develop a learners' ability to reason, solve problems, learn and construct knowledge.

It becomes increasingly necessary to manage complex, ever-changing circumstances. It is therefore necessary to equip health care professionals with change management skills and the ability to initiate change. They need to be innovative and adaptable. In the midst of revolutionary changes, people cannot depend on previously successful ideas. New knowledge and ideas, and novel solutions to problems should be pursued constantly, and therefore health care professionals must be committed to being flexible and lifelong learners (De Villiers, 2001:32). It is therefore necessary to apply educational strategies that support self-directed learning through discovery.

Health care professionals are required to be technologically literate and exhibit a global vision. They ought to be able to utilise information-communication technologies by applying the relevant technical and psychomotor skills. It is also necessary to learn how to function and communicate in virtual reality. Computerassisted instruction and computer-based learning could contribute towards developing these competencies in learners.

The critical paradigm would be a suitable educational foundation for health sciences education, aimed at preparing learners to manage the influences of globalisation at local level. Its fundamental interest is social transformation towards a better, more just society through the emancipation and empowerment of people, so that they can engage in the autonomous actions that arise out of authentic and critical insights into the social construction of human society (Freire, 1972:20, 30-31; Grundy, 1987:18, 99, 106; Rajah, 1993:99-100). Edu- 
cation should focus on helping people to gain insight into the power structures within society and the dominant ideological paradigm, which may result in peoples' position of powerlessness (Grundy, 1987:19; Lovat \& Smith, 1995:29-31). Within the context of health sciences education, learners should be encouraged to critically judge the existing structural and relational inequalities that negatively impact on the ability of local communities to reap the benefits of globalisation, with regard to health and development.

In accordance with the critical paradigm, individuals and groups should be empowered to question current ideas in order to free themselves from ungrounded beliefs and attitudes (Siegel in Bandman \& Bandman, 1995:7). The individual should be empowered to engage in autonomous, but responsible actions, to bring about change to the current, imperfect state of affairs (Freire, 1972:24; Grundy, 1987:19, 113; Lovat \& Smith, 1991:105). Health sciences education ought to enable learners to redefine themselves as persons able to transcend cultural, political, financial and infrastructural constraints in order to act as agents of change, contributing to enhanced health and development in a globalised world. Learners should reflect upon how society shapes their perceptions about themselves and their abilities to contribute towards change. In other words, they ought to be assisted in perceiving themselves as contributors towards a better society, as opposed to victims of globalisation.

The basic disposition of the critical paradigm is critical reflection (Grundy, 1987:124) - a process of constructing and reconstructing the world reflectively through a process of constructing meaning. This is achieved through dialectic interactions between the actions and reflections that the individual engages in, thus promoting an understanding of the world (Freire, 1972:99; Grundy, 1987:104, 113, 115). Grundy (Ford \& ProfettoMcGrath, 1994:342) describes these interactions as follows: "Action is informed by reflection, and reflection is informed by action. Praxis is not action that maintains the status quo, but rather action that changes both the world and our understanding of it".

From the perspective of the critical paradigm, the learning process centres on social issues and realities in the real world. Learning occurs in concrete situations and requires actions as well as intellectual responses. A critical focus is maintained and learning is regarded as a process of interpretation and constructing meaning (Grundy, 1987:103; Rajah, 1993:99). Health sciences education must therefore apply the principles of problem-based, community-based, and experiential learning. Learners need to be equipped with a sound knowledge base about the specific problems and issues that prevail in the setting in which they live and work and the global tendencies that influence community life.

According to the critical paradigm, learning is a social process characterised by dialogue and negotiations (Grundy, 1987:102-107, 115). It is a social construction of personal knowledge through a process of internalisation (Cobb in Gravett \& Henning, 1998:61). This implies that the principles of social constructivism and collaborative learning should be applied in health sciences education. Learner collaboration ought to occur in the physical classroom and in virtual reality.

It is proposed that the curriculum content of existing educational programmes for health care professionals should include at least the following topics:

- the phenomenon of globalisation;

- basic economic principles;

- basic technological studies;

- cultural studies;

- the concept of community empowerment, applied to globalisation; and

- ethos and professional practice applied to globalisation.

The skills component of health sciences education should include:

- cognitive skills;

- interpersonal skills, with specific reference to advocacy, collaboration and negotiation;

- information skills;

- technological literacy; and

- basic web site design.

\section{CONCLUSION}

The benefits and pitfalls of globalisation are numerous. Health care professionals ought to embrace globalisation and ensure that their communities benefit optimally from it in terms of improved health and development. On the other hand, it is necessary to ensure that their communities are protected from the 
negative consequences of globalisation. Health sciences education programmes ought to be revised in order to prepare health care professionals to fulfil this expanded role.

\section{REFERENCES}

BANDMAN, EL \& BANDMAN, B 1995: Critical thinking in nursing; $2^{\text {nd }}$ edition. Connecticut: Appleton \& Lange.

DE VILLIERS, L 2001: Utilising technology in nursing education. Health SA Gesondheid, 6(3):31-43.

DE VILLIERS, L \& TJALE A 2004: Principles of cultural assessment. (In: Tjale, A \& De Villiers, L eds. 2004: Cultural issues in health and health care. Cape Town: Juta, pp 159-174).

DE VILLIERS, MR 1998: Instructional theories of experts: A practical implementation. SA Journal for Higher Education, 12(2):204214.

EVANS, T 1992: The globalisation of capitalism: A celebration of the triumph of free market sophistication. http:// www.libertarian.co.uk/lapubs/socin/socin016.pdf.

FORD, JS \& PROFETTO-MCGRATH, J 1994: A model for critical thinking within the context of curriculum as praxis. Journal of Nursing Education, 33(8):341-344.

FREIRE, P 1972: Pedagogy of the oppressed. Harmondsworth: Penguin.

FRIEDMAN, TI 2000: The lexus and the olive tree. New York: Anchor Books.

FRY, PS 1992: Fostering children's cognitive competence through mediated learning experiences. Frontiers and futures. Springfield: Charles $C$ Thomas.

GIDDENS, A 1999a: Runaway world. Lecture 1: Globalisation. htpp://www.news.bbc.co.uk/hi/English/static/events/reith_99/ week1/week1.htm.

GIDDENS, A 1999b: Runaway world. Lecture 2: Risk. htpp:// www.news.bbc.co.uk/hi/English/static/events/reith_99/week2/ week2.htm.

GIDDENS, A 1999d: Runaway world. Lecture 4: Family. htpp:// www.news.bbc.co.uk/hi/English/static/events/reith_99/week4/ week4.htm.

GIDDENS, A 1999e: Runaway world. Lecture 5: Globalisation. htpp://www.news.bbc.co.uk/hi/English/static/events/reith_99/ week5/week5.htm.

GIGER, JN \& DAVIDHIZAR, RE 1999: Transcultural nursing. Assessment and intervention; $3^{\text {rd }}$ edition. St Louis: Mosby.

GRAVETT, S \& HENNING, E 1998: Teaching as dialogic mediation: A learning centred view of higher education. SA Journal for Higher Education, 12(2):60-68.

GREENBERG, J \& BARON, RA 2003: Behavior in organizations; $8^{\text {th }}$ edition. New Jersey: Pearson Education International.
GREENSTAR 2005: Greenstar solar community center. Retrieved from http://www.greenstar.org on 21/09/2005

GRUNDY, S 1987: Curriculum: Product or praxis. Philadelphia: Falmer.

KGWATALALA, G 2003: Health seeking behaviour of members of the African Gospel Church. Pretoria: University of South Africa. (Unpublished M thesis).

KHOZA, R 1994: African humanism. Ekhaya Promotions: Diepkloof Extension SA.

KOTZE, JC 1993: In their shoes: Understanding black South Africans through their experience of life. Kenwyn: Juta

LOUW, DJ 2001: Unmasking the forces behind and beyond: A practical theological assessment of an African Renaissance. Practical Theology in SA, 16(1):40-61.

LOVAT, TJ \& SMITH, DL 1991: Curriculum: Action on reflection. Wentworth Falls: Social Science.

LOVAT, TJ \& SMITH, DL 1995: Curriculum: Action on reflection revisited; $3^{\text {rd }}$ edition. Wentworth Falls: Social Science.

LUBBE, GJA 2004: Health care for people of different faiths. (In: Tjale, A \& De Villiers, L eds. 2004: Cultural issues in health and health care. Cape Town: Juta, pp 73-105).

MAKHUDU, N 1993: Cultivating a climate for cooperation through Ubuntu Enterprise, 68(August):40-41.

MALAN, JS 1989: Ontwikkeling vanuit die kognitiewe antropologie.

Suid-Afrikaanse Tydskrif vir Etnologie, 12(2):39-49.

MBIGI, L \& MAREE, J 1995: Ubuntu. The spirit of African transformation management. Randburg: Knowledge Resources.

NETAID 2005: Join the fight against poverty. Retrieved from http:/ /www.netaid.org on 21/09/2005.

PRINSLOO, ED 2001: A comparison between medicine from an African (Ubuntu) and Western philosophy. Curations, 24(1):5865.

PRINSLOO, EH 1998: Ubuntu culture and participatory management. (In: Coetzee, PH \& Roux, APJ eds 1998: Philosophy from Africa: A text of readings. London: Thompson, pp 41-51).

RAJAH, DS 1993: Paradigms in teacher education. South African Journal for Higher Education, 7(1):95-102.

TEFFO, J 1994: The concept of Ubuntu as a cohesive moral value. Pretoria: Ubuntu School of Philosophy. 